\title{
ETHANOL PRODUCTION BY CO-CULTIVATION OF YEAST AND LACTIC ACID BACTERIA ON STARCH
}

\author{
M.O. Fomina, O.D. Ianieva, M.V. Havrylenko, \\ T.M. Golovach, V.S. Pidgorskyi \\ Zabolotny Institute of Microbiology and Virology, NAS of Ukraine, \\ 154 Acad. Zabolotny Str., 154, Kyiv, 03143, Ukraine \\ e-mail: M.Fomina@ukr.net
}

The co-cultivation of GRAS amylolytic bacteria together with ethanol-producing yeast Saccharomyces cerevisiae in starch-containing media might be one of the ways solving the problem of starch-containing waste disposal with simultaneous formation of ethanol as a potential biofuel for increasing octane number of gasoline. The aim of the study was to test the combination of microorganisms (amylolytic lactic acid bacteria and yeast) suitable for co-cultivation on starch and to optimize the conditions for starch cofermentation. Methods. Conventional microbiological, biochemical and statistical methods, including serial dilution technique with counting colony forming units (CFU) for growth assessment of mixed cultures, Gas Chromatograph/Mass Spectrometer (GC/MS) for measuring ethanol concentration and Box-Behnken experimental design (Statistica 10) for bioethanol production optimization, were used in this work. Results. The combination of microorganisms for mixed cultures co-cultivation in single-stage starch fermentation was established: the strain of ethanol-producing yeast S. cerevisiae UCM Y-527 and the amylolytic strain of lactic acid bacteria Streptococcus bovis IMV B-7151. Mathematical simulation using a Box-Behnken (3k-p) design determined the optimal parameters for the fermentation of starch in the process of co-cultivation of yeast and bacteria: $10 \mathrm{~g} / L$ of starch in the medium at simultaneous inoculations of both cultures and co-cultivation for 72 hours. The theoretically obtained parameters data were experimentally verified: the maximum ethanol yield $1.95 \mathrm{~g} / \mathrm{L}$ in the experiment corresponded to the theoretically calculated values. Conclusions. It was suggested and optimized a method of starch cofermentation using strains of amylolytic lactic acid bacteria $S$. bovis IMV B-715I and yeast $S$. cerevisiae UCM Y-527, which can be used for one-stage process of hydrolysis and fermentation of starch and starchcontaining wastes with the production of bioethanol and microbial biomass.

Keywords: ethanol, starch, co-cultivation, Saccharomyces cerevisiae, Streptococcus bovis.

The conversion of food or agriculture waste into various valuable compounds, in particular bioethanol, is an upcoming area of biotechnology which has been attracting increasing attention of the researchers [1]. One of the sources for the production of such liquid biofuels as bioethanol is starch-containing substrates [2-3], which are cheap and common raw materials all over the world. Significant volumes of starch-containing wastewater from the processing of starchy substrates, which are characterized by high levels of chemical oxygen demand (COD), are produced every year [4]. Ukraine is one of the world leaders in corn and potato production. As a result of potato processing 5-20\% of the product goes to waste [5], most of which is not disposed of causing serious environmental concerns $[6,7]$.
In this regard, the development of costeffective ethanol production processes from starchcontaining substrates is one of the important and environmentally promising areas of biotechnology. Conventional bioconversion of starch to ethanol is a three-step process [6]. The first stage is the substrate gelatinization, the second stage is the saccharification, in which the starch is hydrolyzed to simple sugars using either toxic for the environment acid hydrolysis or rather expensive amylolytic enzymes (glucoamylase and alpha-amylase), since amylolytic activity is uncharacteristic for the most effective ethanologenic yeast Saccharomyces cerevisiae. The third step is fermentation, in which the yeast $S$. cerevisiae or other microorganisms ferment the sugars, resulting from the starch hydrolysis, producing ethanol. Thus, eliminating the 
need for enzymatic saccharification in bioethanol production is a key step in reducing its cost [8-10]. To solve this problem, an alternative onestep process of bioconversion of starch to bioethanol could be the use of mixed microbial cultures, where ethanologenic yeasts are co-cultivated with other microorganisms capable of starch saccharification. In this regard, the selection of the most effective amylolytic microorganisms and determination of the optimal conditions for starch fermentation under the conditions of their co-cultivation with yeast is an important and necessary step towards solving the problem of starch-containing waste utilization resulting in simultaneous formation of ethanol as biofuels for increasing octane number of gasoline.

One of the most common and safest for use in the industry microorganisms that may co-exist in association with ethanol producing yeasts are lactic acid bacteria (LAB), some of which have the ability to hydrolyze starch [11-15]. It was worth to explore the amylolytic potential of LAB strains as the saccharification agents in the one-step process of bioconversion of starch to bioethanol.

The aim of the work was to determine the optimal conditions for ethanol production from starch during co-cultivation of the selected strains of amylolytic LAB and ethanol-producing yeast.

Materials and methods. Microbial strains. To select LAB able to hydrolyze starch, 1011 LAB strains of genera Enterococcus, Lactobacillus and Streptococcus from the Ukrainian Collection of Microorganisms (UCM) and the Collection of Lactic Acid Bacteria (Department of Physiology of Industrial Microorganisms, D.K. Zabolotny Institute of Microbiology and Virology of the NAS of Ukraine) were preliminary screened for their amylolytic activity by qualitative analysis using iodine Lugol's solution, staining starch in the agar medium and visualizing the clear zones of starch hydrolysis around microbial colonies [13]. These strains have been previously isolated from different natural ecological niches: insects, fish, various species of farm animals (calves, sheep, pigs, poultry), their feed, silage, wine, milk and other dairy products, rhizosphere and epiphytic microbiota of plants, as well as human digestive tract [13]. Three strains of ethanol-producing S. cerevisiae yeasts (UCM Y-526, UCM Y-527 and UCM Y-528), isolated from alcohol industry enterprises, were obtained from the Ukrainian Collection of Microorganisms. As a result of preliminary screening yeast strain $S$. cerevisiae
UCM Y-527 and isolated from silage amylolytic LAB strain Streptococcus bovis IMV B-7151 were used in the subsequent experiments.

Physiological and biochemical properties of selected $L A B$ were determined according to [13$16]$.

The chosen LAB strain $S$. bovis IMV B-7151 was deposited at UCM-depository where it was kept in lyophilized form for over 30 years. Prior to deposition, its amylolytic activity was quantified colorimetrically by a decrease of starch concentration according to [14], where one unit of amylolytic activity represented the hydrolysed starch in grams either per $1 \mathrm{~g}$ of biomass or per 100 $\mathrm{mL}$ of cell-free culture supernatant obtained after one hour exposure at $37^{\circ} \mathrm{C}$ and $\mathrm{pH} 6.4$ in the Meat Peptone Broth (MPB) medium with $0.5 \%$ soluble starch.

In all other cases bacterial amylolytic activity was assessed by qualitative analysis as mentioned above [13].

The bacterial growth rate was established by periodic cultivation [15] using starch and non-starch liquid media: MPB, MPB $+2 \%$ glucose and MPB $+0.5 \%$ starch (inoculum $10^{6} \mathrm{CFU} / \mathrm{mL}$ ). Bacterial biomass was determined spectrophotometrically.

Assessment of antagonism between yeast and bacterial strains. Antagonistic relationship between S. cerevisiae UCM Y-527 and S. bovis IMV B-7151 was determined using the cross-streaking test on YPD agar and nutrient agar containing $2 \%$ glucose. Plates were incubated for $48-72$ hours at $30{ }^{\circ} \mathrm{C}$ [17].

Preparation of inoculum for yeast/bacteria cocultivation. The strain $S$. cerevisiae UCM Y-527 was grown in YPD liquid medium $(10 \mathrm{~g} / \mathrm{L}$ yeast extract, $20 \mathrm{~g} / \mathrm{L}$ glucose, $20 \mathrm{~g} / \mathrm{L}$ peptone) at $30{ }^{\circ} \mathrm{C}$ and $220 \mathrm{rpm}$ for 18-20 hours to the late exponential phase. S. bovis IMV B-7151 was grown in YPS liquid medium $(10 \mathrm{~g} / \mathrm{L}$ yeast extract, $10 \mathrm{~g} / \mathrm{L}$ starch, $20 \mathrm{~g} / \mathrm{L}$ peptone) at $37{ }^{\circ} \mathrm{C}$ and $220 \mathrm{rpm}$ for 14 16 hours to the late exponential phase.

Conditions of co-cultivation of yeast and bacteria. The co-cultivation of $S$. bovis IMV B-7151 and S. cerevisiae UCM Y-527 was carried out in YPS liquid medium, containing $10 \mathrm{~g} / \mathrm{L}$ yeast extract, $20 \mathrm{~g} / \mathrm{L}$ peptone and different concentrations of soluble starch as the sole carbon source, at $30{ }^{\circ} \mathrm{C}$ under microaerophilic (static) conditions (without shaking) in $250 \mathrm{~mL}$ flasks with rubber stoppers with exhaust tubes containing $200 \mathrm{~mL}$ of the medium. The effect of cultivation factors on ethanol production during the co-cultivation of $S$. bovis IMV B-7151 and 
S. cerevisiae UCM Y-527 was determined by means of a multifactorial experiment. A multifactor experimental design is presented in Tables 1 and 2. The studied factors for mathematical modelling of ethanol production were: $\boldsymbol{X}_{\boldsymbol{1}}-$ starch concentration from 2 to $10 \mathrm{~g} / \mathrm{L} ; \boldsymbol{X}_{2}$ - the duration of pre-cultivation of S. bovis IMV B-7151 alone, ranging from $0 \mathrm{~h}$ (simultaneous yeast inoculation with bacteria) up to 6 hours, and $\boldsymbol{X}_{3}$ - the duration of co-cultivation of yeast and bacterial strains ranging from 24 to 72 hours (Table 1). Table 1 also shows the fixed initial parameters of cultivation of $S$. cerevisiae UCM Y-527 and S. bovis IMV B-7151. The matrix of Box-Behnken experimental design for the yeast/bacteria co-cultivation is presented in Table 2.

Biomass yield in the experiments on yeastbacterial co-cultivation was assessed by CFU using the serial dilutions technique inoculating cells suspensions on malt extract agar (MEA) for yeasts and YPS agar for bacteria.

Determination of ethanol concentration. Ethanol concentration in the medium was determined by gas chromatography-mass spectrometry using the Agilent 6890N / 5973inert (Agilent Technologies, USA) capillary column HP-INNOWax $(30 \mathrm{~m} \times$ $0.25 \mathrm{~mm} \times 0.25 \mathrm{~mm})(\mathrm{J} \& \mathrm{~W}$ Scientific, USA). The external standard calibration was performed using ethanol (Ethyl alcohol $\geq 99.8 \%$, Sigma-Aldrich) as a standard. Separation was performed with a temperature gradient of $20{ }^{\circ} \mathrm{C} / \mathrm{min}$ from 40 to $120^{\circ} \mathrm{C}$, the carrier gas was helium, the flow rate through the column was $1 \mathrm{~mL} / \mathrm{min}$.

Statistical analysis of the obtained data (ANOVA, construction of response surfaces) was performed using Statistica 10 (StatSoft Ink., 2011). The results obtained were considered statistically significant at $\mathrm{p} \leq 0.05$.

Table 1

Mathematical model of ethanol production by yeast/bacterial co-cultivation on starch: factors and fixed initial parameters of the process

\begin{tabular}{|c|c|c|c|c|}
\hline \multirow{2}{*}{\multicolumn{2}{|c|}{ Factor }} & \multicolumn{3}{|c|}{ Levels of factor } \\
\hline & & -1 & $\mathbf{0}$ & +1 \\
\hline \multicolumn{2}{|c|}{ Starch concentration in a medium $\left(\boldsymbol{X}_{1}\right), \mathrm{g} / \mathrm{L}$} & 2 & 6 & 10 \\
\hline \multicolumn{2}{|c|}{ Duration of pre-cultivation of $S$. bovis IMV B-7151 $\left(\boldsymbol{X}_{2}\right), \mathrm{h}$} & 0 & 3 & 6 \\
\hline \multicolumn{2}{|c|}{$\begin{array}{l}\text { Duration of co-cultivation of } S \text {. bovis IMV B-7151 and } \\
\text { S. cerevisiae UCM Y-527 }\left(\boldsymbol{X}_{3}\right), \mathrm{h}\end{array}$} & 24 & 48 & 72 \\
\hline \multicolumn{5}{|c|}{$\begin{array}{ll}\text { Initial parameters of the process } \\
\end{array}$} \\
\hline S. cerevisiae inoculum CFU/mL & S. bovis inoculum CFU/mL & \multicolumn{3}{|c|}{ pH of medium } \\
\hline $7.55 \times 10^{6}$ & $1.15 \times 10^{8}$ & \multicolumn{3}{|c|}{6.0} \\
\hline
\end{tabular}

\section{Table 2}

The matrix of Box-Behnken experimental design

\begin{tabular}{|l|c|c|c|}
\hline Variant & $\begin{array}{c}\text { Starch concentration } \\
\text { in medium }\left(X_{1}\right), \mathrm{g} / \mathrm{L}\end{array}$ & $\begin{array}{c}\text { Duration of pre-cultivation } \\
\text { of } S . \text { bovis }\left(X_{2}\right), \mathrm{h}\end{array}$ & $\begin{array}{c}\text { Duration of yeast/bacteria } \\
\text { co-cultivation }\left(X_{3}\right), \mathrm{h}\end{array}$ \\
\hline $\mathbf{1}$ & 2 & 0 & 48 \\
\hline $\mathbf{2}$ & 10 & 0 & 48 \\
\hline $\mathbf{3}$ & 2 & 6 & 48 \\
\hline $\mathbf{4}$ & 10 & 6 & 48 \\
\hline $\mathbf{5}$ & 2 & 3 & 24 \\
\hline $\mathbf{6}$ & 10 & 3 & 24 \\
\hline $\mathbf{7}$ & 2 & 3 & 72 \\
\hline $\mathbf{8}$ & 10 & 3 & 72 \\
\hline $\mathbf{9}$ & 6 & 0 & 24 \\
\hline $\mathbf{1 0}$ & 6 & 6 & 24 \\
\hline $\mathbf{1 1}$ & 6 & 0 & 72 \\
\hline $\mathbf{1 2}$ & 6 & 6 & 72 \\
\hline $\mathbf{1 3}$ & 6 & 3 & 48 \\
\hline $\mathbf{1 4}$ & 6 & 3 & 48 \\
\hline $\mathbf{1 5}$ & 6 & 3 & 48 \\
\hline
\end{tabular}


Results. Out of 1011 tested strains of LAB only 41 strains showed the ability to hydrolyze starch, including one strain S. bovis IMV B-7151, isolated from rye/sainfoin silage, which demonstrated a stable amylolytic activity. This strain maintained its amylolytic activity for over 30 year storage. It was characterized by the set of biotechnologically relevant criteria including the ability to ferment pentoses and hydrolyze polysaccharides (including starch); a high specific growth rate in glucose- or starch-containing media $\left(1.75-2.00 \mathrm{~h}^{-1}\right)$; a wide growth temperature range (optimal: $25-48{ }^{\circ} \mathrm{C}$, limiting: $10-50{ }^{\circ} \mathrm{C}$ ); the ability to produce lactic acid and lower $\mathrm{pH}$ of the medium to 4.2 , with the optimal for growth $\mathrm{pH}$ values 5.5-7.5; the absence of indole and hydrogen sulfide production; and high xero- and osmotolerance (Table 3). The amylolytic activity of $S$. bovis IMV B-7151 was 6-8 Units per g biomass and 1.53 Units per $100 \mathrm{~mL}$ of cell-free culture supernatant. Under conditions of batch cultivation in liquid medium (MPB), the bacterial growth rate and biomass yield was much higher when the medium was supplemented with glucose $(2 \% \mathrm{w} / \mathrm{v})$ or soluble starch $(0.5 \% \mathrm{w} / \mathrm{v})$ with similar values for both carbon substrates (Fig.1). Considering the stable amylolytic activity and growth stimulation by the presence of starch in the medium along with other biotechnologically beneficial properties, the strain S. bovis IMV B-7151 was selected as the most promising microorganism for co-cultivation of LAB with ethanologenic yeast in starch-containing media.

The preliminary screening of three ethanolproducing strains of $S$. cerevisiae did not reveal any statistically significant difference in their growth and ethanologenic performance in the glucosecontaining medium (YPD), with $S$. cerevisiae UCM Y-527 being slightly more efficient ethanolproducing strain, although without statistically significant difference. All yeast strains were tested

Table 3

\begin{tabular}{|c|c|c|}
\hline \multicolumn{3}{|c|}{ Physiological and biochemical characteristics of $S$. bovis IMV B-7151 } \\
\hline Parameters & \multicolumn{2}{|c|}{$\begin{array}{l}\text { Description } \\
\end{array}$} \\
\hline Temperature range & \multicolumn{2}{|c|}{ Growth at $+5-+54{ }^{\circ} \mathrm{C}$} \\
\hline Xero- /Osmo-tolerance & \multicolumn{2}{|c|}{ Growth at $<9 \% \mathrm{NaCl}$} \\
\hline \multirow{3}{*}{ Polysaccharides hydrolysis } & Starch & ++++ \\
\hline & Dextrin & +++ \\
\hline & Amylose & +++ \\
\hline Fermentation of pentoses & $\begin{array}{l}\text { D-xylose } \\
\text { Arabinose }\end{array}$ & $\begin{array}{l}++{ }_{\text {(slow) }} \\
+++{ }^{2}\end{array}$ \\
\hline \multirow{2}{*}{ Production of acids from glucose } & Lactic & $0.3 \%$ \\
\hline & Acetic & $0.03 \%$ \\
\hline Limiting $\mathrm{pH}$ level in the acidic range & \multicolumn{2}{|c|}{4.28} \\
\hline Specific growth rate & \multicolumn{2}{|c|}{$1.5-2.0 \mathrm{~h}^{-1}$} \\
\hline
\end{tabular}

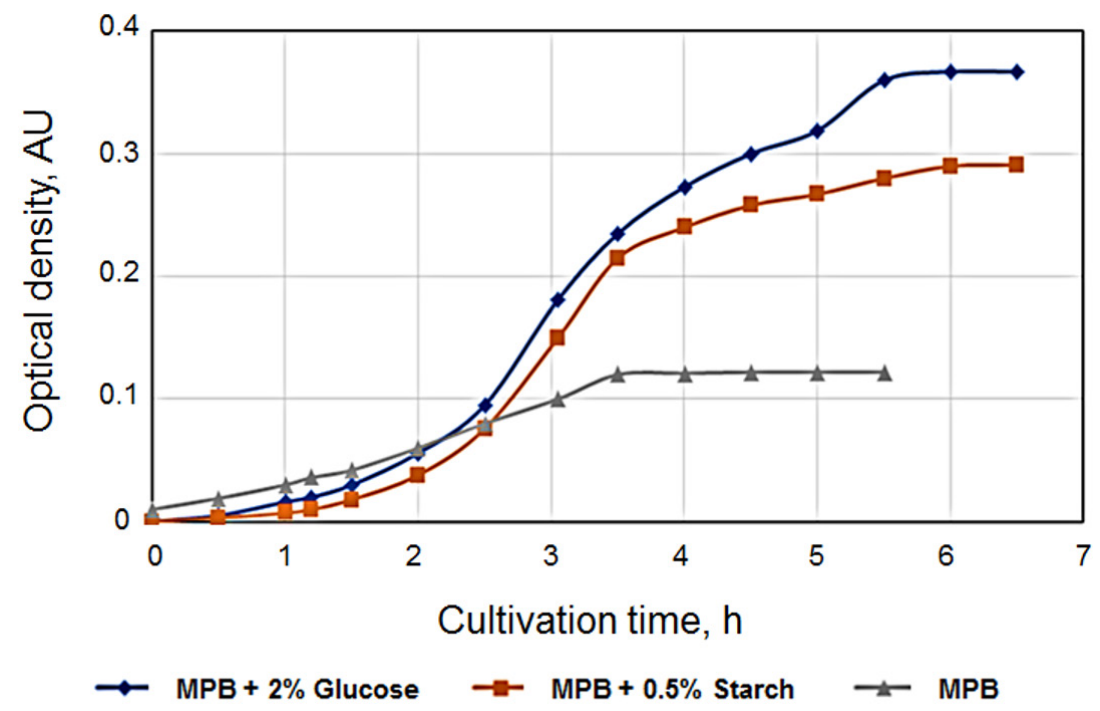

F i g. 1. Growth of $S$. bovis IMV B-7151 in various media: MPB, MPB $+2 \%$ glucose and MPB + $0.5 \%$ starch $(\lambda=580 \mathrm{~nm}$; standard error of the mean did not exceed $8.5 \%$; AU - arbitrary unit) 
The visual assessment of the effects of the studied cultivation parameters on the ethanol yield by using the analysis of variance is presented in Fig. 3 as Pareto diagram, where the effects are arranged in the descending order of the absolute value. This diagram shows that the linear effect of the initial concentration of starch had the maximum significant effect, and the linear effect of the duration of $S$. bovis pre-cultivation had the least.

This analysis resulted in the equation in the form of the second-order quadratic polynomial as the experimental model, describing the dependence of ethanol concentration on the combination of the studied factors and their interactions, where $\boldsymbol{Y}$ is the predicted response, $\boldsymbol{X}_{1}, \boldsymbol{X}_{2}$ and $\boldsymbol{X}_{3}$ are the independent variables:

(1) Starch concentration, g/l

(1) Starch concentration, g/l

(3) Duration of co-cultivation, $h$ (L)

(2) Duration of pre-cultivation of $S$. bovis, $h$

(3) Duration of co-cultivation, $\mathrm{h}$

(2) Duration of pre-cultivation of $S$. bovis, $h$

$$
\begin{aligned}
& \quad Y=0.5675+0.9583 \cdot X_{1}-0.1417 \cdot X_{2}+ \\
& +0.4083 \cdot X_{3}-0.3354 \cdot X_{1}{ }^{2}-0.0204 \cdot X_{2}{ }^{2}+ \\
& +0.0396 \cdot X_{3}{ }^{2}-0.075 \cdot X_{1} X_{2}-0.1000 \cdot X_{1} X_{2}{ }^{2}+ \\
& +0.0200 \cdot X_{1}{ }^{2} X_{2}+0.5150 \cdot X_{1} X_{3}-0.1600 \cdot X_{1}{ }^{2} X_{3}- \\
& -0.1150 \cdot X_{2} X_{3}
\end{aligned}
$$

According to the obtained model, the concentration of starch in the medium $\boldsymbol{X}_{1}$ was the most significant factor with positive linear effect on the ethanol yield $(\mathrm{F}=1340.3 ; \mathrm{p}=0.0007)$. The ethanol yield increase was also positively linearly affected by the duration of co-cultivation of two strains $\boldsymbol{X}_{3}(\mathrm{~F}=243.3 ; \mathrm{p}=0.004)$, as well as the linear interaction of $\boldsymbol{X}_{1}$ and $\boldsymbol{X}_{3}(\mathrm{~F}=215.0 ; \mathrm{p}=0.0046)$. The duration of $S$. bovis pre-cultivation $\boldsymbol{X}_{2}$ was a less significant factor $(F=29.2 ; p=0.0324)$ with a negative linear effect on the ethanol production.
(L) (Q) (L) 1Lby3L 1Qby3L

(L) 1Lby2Q 2Lby3Q

(Q) 1Lby2L

(Q) 1Qby2L

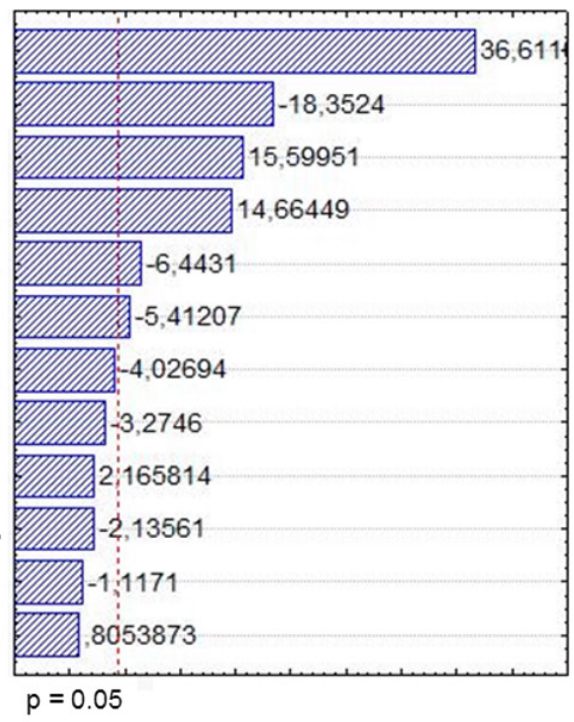

F i g. 3. Pareto chart visualizing the effects of the cultivation parameters on the ethanol yield during co-fermentation of $S$. bovis and $S$. cerevisiae

The interaction effects of the cultivation parameters $\left(\boldsymbol{X}_{1}, \boldsymbol{X}_{2}\right.$ and $\left.\boldsymbol{X}_{3}\right)$ on the ethanol production were visualized using the response surface method (Fig. 4).

The response surface plots showed that ethanol yield increases with the simultaneous increase of two factors: starch concentration $X_{1}$ and duration of co-cultivation of the producer strains $\boldsymbol{X}_{3}$ (Fig. 4A). The highest ethanol yield was observed at starch concentration above $9 \mathrm{~g} / \mathrm{L}$ with a duration of cocultivation process of $60-80$ hours.

In combination with either starch concentration $X_{1}$ or duration of co-cultivation $\boldsymbol{X}_{3}$, the duration of $S$. bovis pre-cultivation $\boldsymbol{X}_{2}$ had negligible effect on the ethanol yield, but the highest production was observed when cultivating $S$. bovis for less than 2 hours (Fig. 4B, C).
The calculated optimal values for the studied cultivation parameters were: $10 \mathrm{~g} / \mathrm{L}$ of starch, simultaneous inoculation of both cultures $\left(X_{2}=0\right)$ and $72 \mathrm{~h}$ of co-cultivation. Deviation from the calculated data will invariably lead to a decrease in ethanol yield. The predicted in silico value of ethanol concentration was $1.87 \pm 0.15 \mathrm{~g} / \mathrm{L}$.

To experimentally verify the theoretically calculated values of the parameters of the combined $S$. cerevisiae UCM Y-527/S. bovis IMV B-7151 fermentation, the co-cultivation of these microorganisms was carried out under the calculated optimal conditions: the substrate (starch) concentration of $10 \mathrm{~g} / \mathrm{L}$ and simultaneous inoculation of both microbial strains (Table 5). The duration of cultivation was 2, 3 or 4 days. The maximum ethanol yield $1.95 \mathrm{~g} / \mathrm{L}$ was observed 
on the $3^{\text {rd }}$ day of cultivation, which corresponded to the theoretically calculated parameters under these conditions. The co-cultivation of the tested strains up to 4 days did not increase the ethanol production.

Discussion. Both saccharolytic and ethanologenic abilities of microorganisms are essential in the process of bioconversion of starch and sugar feedstocks into bioethanol. The saccharolytic ability is referred to the hydrolysis or metabolism of carbohydrate oligomers or polymers, including starch, whereas ethanologenic ability specified the production of ethanol as a main product $[18,19]$.
Almost all world commercial ethanol production is currently accounted for by fermentation by a single species monoculture of $S$. cerevisiae, which has been the predominant ethanologenic microorganism used since ancient times. In nature, it is rare for a certain microorganism to possess both ethanologenic and saccharolytic capabilities optimally expressed, either concurrently or sequentially. Therefore one of the actively explored approaches for consolidated bioprocessing for ethanol production is a use of co-cultivation/cofermentation of mixed cultures of saccharolytic and ethanologenic microorganisms [18-20].
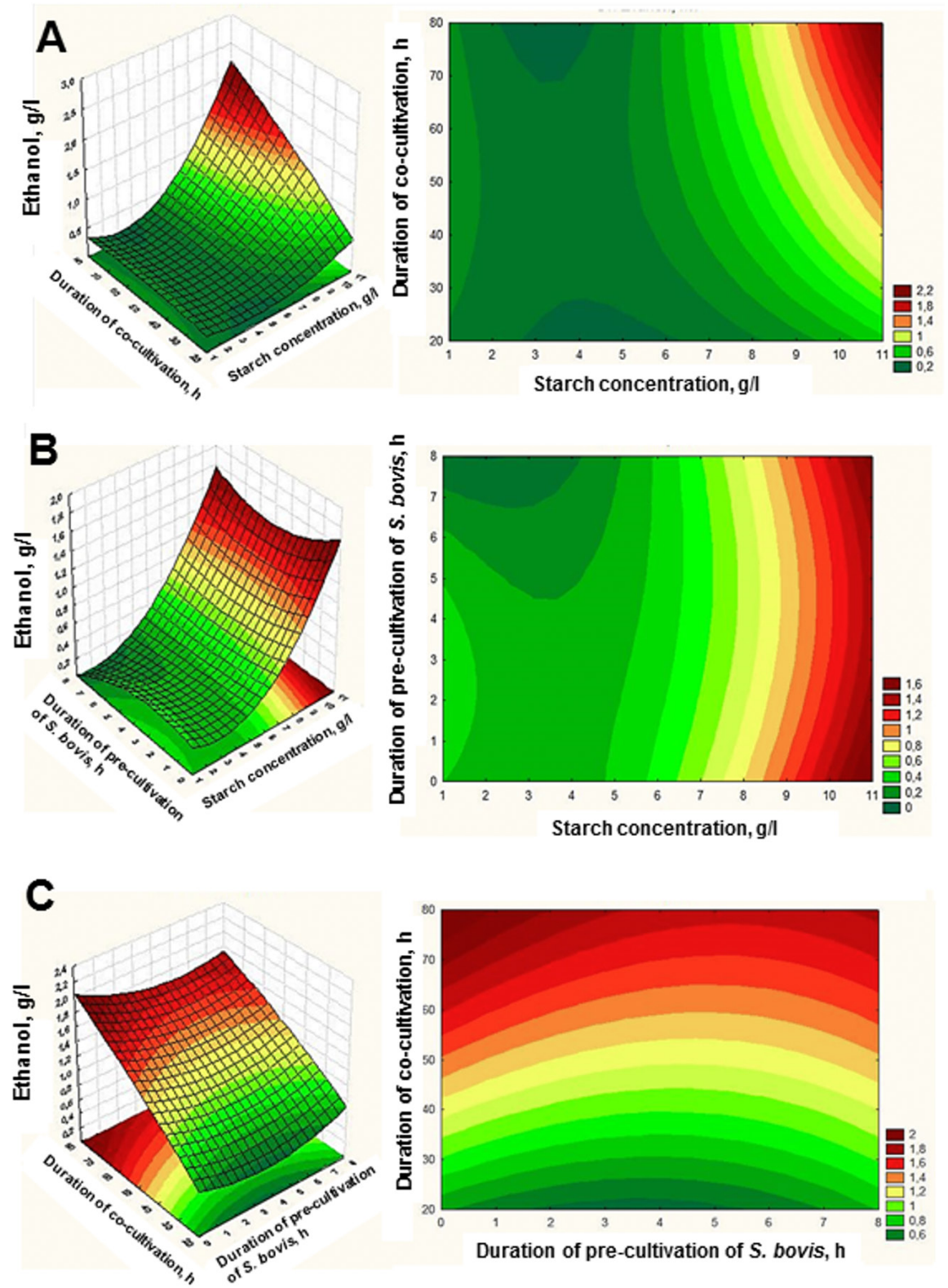

F i g. 4. The response surface plots of the interaction effects of the cultivation parameters: (A) starch concentration $X_{1}$ versus the duration of co-cultivation $X_{3} ;(B)$ starch concentration $X_{1}$ versus the duration of $S$. bovis pre-cultivation $X_{2}$; and (C) the duration of $S$. bovis pre-cultivation $X_{2}$ versus the duration of co-cultivation $X_{3}$, on the ethanol production 
Co-cultivation of $S$. cerevisiae UCM Y-527 and $S$. bovis IMV B-7151 under the theoretically predicted optimal conditions

\begin{tabular}{|l|c|c|c|c|}
\hline $\begin{array}{l}\text { Duration of } \\
\text { cultivation, days }\end{array}$ & $\begin{array}{c}\text { Final biomass of } \\
\text { S. cerevisiae CFU/mL }\end{array}$ & $\begin{array}{c}\text { Final biomass of } \\
\text { S. bovis CFU/mL }\end{array}$ & Final pH & $\begin{array}{c}\text { Ethanol } \\
\text { concentration, g/L }\end{array}$ \\
\hline $\mathbf{2}$ & $(9.02 \pm 0.51) \times 10^{7}$ & $(5.88 \pm 0.25) \times 10^{8}$ & $4.4 \pm 0.17$ & $1.24 \pm 0.09$ \\
\hline $\mathbf{3}$ & $(1.2 \pm 0.07) \times 10^{8}$ & $(4.2 \pm 0.36) \times 10^{8}$ & $4.5 \pm 0.06$ & $1.95 \pm 0.04$ \\
\hline $\mathbf{4}$ & $(7.87 \pm 0.20) \times 10^{7}$ & $(3.83 \pm 0.1) \times 10^{8}$ & $4.1 \pm 0.00$ & $1.71 \pm 0.18$ \\
\hline
\end{tabular}

Ethanol production from starch-containing substrates using ethanologenic $S$. cerevisiae co-cultivated with other microorganisms with saccharolytic properties has been attempted in several works, where $S$. cerevisiae was combined with amylolytic yeast Schwanniomyces occidentalis [21] or molds Aspergillus niger [22, 23] and Amylomyces rouxii [24], or amylolytic bacteria Bacillus subtilis [25].

Widespread in nature despite their high nutritional requirements, LAB are often the natural partners of various yeasts including $S$. cerevisiae, forming mutually beneficial "cross-feeding"-type relationships within bacteria-yeasts communities in a variety of naturally fermented foods and beverages [15, 26-28]. Yeast is also known to be a natural symbiont for $\mathrm{LAB}$, because the latter can reduce the $\mathrm{pH}$ of the medium to $3.5-4.5$, which is comfortable for the yeast and detrimental to many microorganisms [14, 28, 29]. For example, used in this study silage-isolated strain S. bovis IMV B-7151 acidified medium to $\mathrm{pH}=4.28$. In case of starch-based substrates, ethanologenic yeasts benefit from bacterial amylolytic activity resulting in readily fermented by yeasts hexose sugars, whereas LAB benefit from the nitrogen overflow provided by yeasts, secreting a pool of metabolites with accessible for bacteria forms of nitrogen, especially amino acids $[26,28]$.

$\mathrm{LAB}$, generally, are able to grow in a wide range of temperatures $\left(4-65^{\circ} \mathrm{C}\right)$ and $\mathrm{pH}$ values, and to ferment pentoses; however the ability to hydrolyse starch and dextrins is not characteristic of this group of bacteria and occurs only in some strains. There were reported the attempts to obtain LAB with amylolytic activity using genetically engineered methods [30,31]. In nature, the number of such amylolytic strains can reach 5-9\% of total LAB strains in raw vegetable materials; their percentage in silage does not exceed $0.1-1.0 \%$ and they are also rare in the digestive tract of humans and birds [14, 32, 33]. These amylolytic strains usually belong to Enterococcus, Lactobacillus and Streptococcus genera. It was reported that their ability for starch hydrolysis was often lost rapidly under laboratory conditions while maintaining isolates on media containing glucose or other sugars, indicating the possible association of this activity with plasmids [14]. Our data also demonstrated that only $4.06 \%$ of natural LAB strains originated from various sources manifested ability for starch hydrolysis; and only one silage isolate $S$. bovis IMV B-7151 was able to maintain stable amylolytic activity for several decades under laboratory conditions.

The efficiency of starch conversion to ethanol as a result of co-cultivation of amylolytic strain S. bovis IMV B-7151 and ethanologenic yeast $S$. cerevisiae UCM Y-527 was comparable to the yields obtained by Jeon et al. in the conventional bioreactor [22] and by Syadiah et al. during cocultivation of $S$. cerevisiae and mold Trichoderma reesei [34]. However, more efficient starch conversion to ethanol was demonstrated during simultaneous cultivation of amylolytic molds Amylomyces rouxii and S. cerevisiae [24] or amylolytic yeasts and $S$. cerevisiae [21].

In our study the optimized process of fermentation of starch to obtain liquid biofuels ethanol by co-cultivation of LAB S. bovis IMV B-7151 and yeast strain S. cerevisiae IMV Y-5098 demonstrated that the maximum ethanol yield was limited to a concentration around $2 \mathrm{~g} / \mathrm{L}$. Such ethanol concentration is very characteristic for the case of a natural symbiotic partnership of ethanologenic yeast and LAB known, for example, for fermented foods [26, 27, 32]. It is unlikely that such level of ethanol yield would make this approach feasible for fully scaled industrial use in terms of liquid bioethanol production. Nevertheless it could be successfully used for the treatment and upcycling (recycling with added value) of starchcontaining wastes of food industry and agriculture by their enrichment with yeast and LAB biomass as a GRAS source of various valuable nutrients for potential application in foraging [35]. Since $S$. cerevisiae yeast is the most convenient and studied microorganism for the industrial production 
of not only ethanol but also biomass as a source of protein, amino acids, vitamins, which can be used in the food industry and animal husbandry. Isolated from silage LAB strain $S$. bovis IMV B-7151 demonstrated probiotic activity, inhibition of the growth of opportunistic and phytopathogenic bacteria, high growth rate on starch-containing media, ability to grow in a mixed culture with the ethanologenic yeast $S$. cerevisiae as well as the absence of pathogenicity for warm-blooded animals. The co-cultivation of ethanologenic yeast and LAB on starch in this study has such advantages as (i) one-step process, including rejection of enzyme preparations, the use of high temperatures and mixing of the enzymatic mixture; (ii) the use of strains of microorganisms that are safe for the environment and human and animal health; and (iii) the application of LAB strain with probiotic potential for the starch hydrolysis.

Thus, the co-cultivation of such natural symbiont partners as ethanologenic yeast and $\mathrm{LAB}$, in case of this study amylolytic LAB strain $S$. bovis IMV B-7151 and ethanologenic yeast $S$. cerevisiae UCM Y-527, may enable multi-purpose effective use of mixed cultures including utilization of starch-containing wastes for the one-step process of bioconversion of starch to bioethanol.

Conclusions. As a result of the selection of the strains of amylolytic LAB and ethanologenic yeast and optimization of the conditions for their starch co-fermentation, it was suggested a method of starch co-fermentation using LAB strain $S$. bovis IMV B-7151 and yeast strain $S$. cerevisiae IMV Y-5098, to be used for one-stage process of bioconversion of starch and starch-containing wastes to bioethanol and production of yeast and LAB biomass.

Acknowledgements. The authors thank Dr Maksim A. Kharkhota, a head of Laboratory of biopolymeric compounds, D.K. Zabolotny Institute of Microbiology and Virology of the NASU, for his help with determination of ethanol concentration, and Dr Kateryna Ohirchuk for technical assistance and helpful discussions during optimization of the parameters of the yeast/bacteria co-fermentation.

Financial support. The authors acknowledge the funding of Target Comprehensive Research Program of the National Academy of Sciences of Ukraine "Biological resources and the latest bioenergy conversion technologies" under the contract No. 11-17 (2017).

\section{ОТРИМАННЯ ЕТАНОЛУ ЗА СУМІСНОГО КУЛЬТИВУВАННЯ ДРІЖДЖІВ ТА МОЛОЧНОКИСЛИХ БАКТЕРІЙ НА КРОХМАЛІ}

\author{
М.О. Фоміна, О.Д. Янева, \\ М.В. Гавриленко, Т.М. Головач, \\ В.С. Підгорський
}

Інститут мікробіології і вірусології ім. Д.К. Заболотного НАН України, вул. Академіка Заболотного, 154, Київ, 03143, Україна

Р ез юм е

Сумісне культивування амілолітичних бактерій зі статусом GRAS та етанолсинтезуючих дріжджів Saccharomyces cerevisiae в середовищі, що містить крохмаль, може стати одним із шляхів вирішення проблеми утилізації крохмалевмісних відходів та одночасного отримання етанолу - перспективного біопалива - 3 метою підвищення октанового числа. Метою даної роботи було випробувати комбінацію мікроорганізмів (амілолітичних молочнокислих бактерій та дріжджів), придатних для сумісного культивування на крохмалі, та визначити оптимальні умови для співферментації крохмалю. Методи. В роботі були задіяні традиційні мікробіологічні, біохімічні та статистичні методи, включно з методом серійних розведень, для визначення росту змішаних культур мікроорганізмів, газовою хроматографією/мас-спектрометрією (GC/MS) для визначення концентрації етанолу та планом Бокс-Бенкена для оптимізації умов продукування етанолу. Результати. Визначена комбінація мікроорганізмів для сумісної одностадійної ферментації крохмалю: штам етанолсинтезуючих дріжджів S. cerevisiae УКМ Y-527 та амілолітичний штам молочнокислих бактерій Streptococcus bovis IMB B-7151. Математичне моделювання з використанням плану Бокса-Бенкена (3k-p) визначило оптимальні параметри сумісної ферментації крохмалю в процесі співкультивування дріжджів і бактерій: 10 г/л крохмалю в середовищі, одночасна інокуляція обома штамами мікроорганізмів та тривалість культивування 72 години. Теоретично отримані параметри були експериментально підтверджені: максимальна концентрація етанолу 1,95 г/л за умов експерименту відповідала теоретичним розрахункам. Висновки. Запропоновано та оптимізовано спосіб сумісної ферментації крохмалю з використанням комбінації штамів амілолітичних молочнокислих бактерій S. bovis IMB B-7151 та дріжджів 
S. cerevisiae УКМ Ү-5098, яка може бути задіяна для одностадійного процесу гідролізу та ферментації крохмалю та крохмалевмісних відходів для отримання біоетанолу та мікробної біомаси.

1. Girotto F, Alibardi L, Cossu R. Food waste generation and industrial uses: A review. Waste Manag. 2015; 45:32-41. doi: 10.1016/j.wasman.2015.06.008.

2. Toksoy Oner E, Oliver SG, Kirdar B. Appl Environ Microbiol. 2005; 71(10):6443-5. doi: 10.1128/AEM.71.10.6443-6445.2005.

3. Van Zyl WH, Bloom M, Viktor MJ. Engineering yeasts for raw starch conversion. Appl Microbiol Biotechnol. 2012; 95(6):1377-88. doi: 10.1007/ s00253-012-4248-0. Epub 2012 Jul 14.

4. Bai FW, Anderson WA, Moo-Young M. Ethanol fermentation technologies from sugar and starch feedstocks. Biotechnol Adv. 2008; 26(1):89-105. doi: 10.1016/j.biotechadv.2007.09.002.

5. Kosseva MR. Sources, Characterization, and Composition of Food Industry. In: Kosseva MR, Webb C, editors. Food Industry Wastes. USA: Elsevier; 2013; p. 37-60.

6. Lounglawan P, Khungaew M, Suksombat W. Silage production from cassava peel and cassava pulp as energy source in cattle diets. J Anim Vet Adv. 2011; 10(8):1007-1011. doi: 10.3923/javaa.2011.1007.1011.

7. Gao M-T, Yano S, Inoue H, Sakanishi K. Production of ethanol from potato pulp: Investigation of the role of the enzyme from Acremonium cellulolyticus in conversion of potato pulp into ethanol. Process Biochem. 2012; 47(12):2110-2115. doi: 10.1016/j.procbio.2012.07.031.

8. Kroukamp H, Mert M, Viljoen-Bloom M, van Zyl WH, Gorgens JF, Haan RD. Engineering Saccharomyces cerevisiae for next generation ethanol production. J Chem Technol Biotechnol. 2013; 88(6):983-991. doi: 10.1002/jctb.4068.

9. Shigechi H, Koh J, Fujita Y, Matsumoto T, Bito Y, Ueda M, Satoh E, Fukuda H, Kondo A. Direct production of ethanol from raw corn starch via fermentation by use of a novel surface-engineered yeast strain codisplaying glucoamylase and 25 alpha-amylase. Appl Environ
Ключові слова: етанол, крохмаль, сумісне культивування, Saccharomyces cerevisiae, Streptococcus bovis.

Microbiol. 2004; 70(8):5037-40. doi: 10.1128/ AEM.70.8.5037-5040.2004.

10. Yamada R, Tanaka T, Ogino C, Fukuda H, Kondo A. Novel strategy for yeast construction using delta-integration and cell fusion to efficiently produce ethanol from raw starch. Appl Microbiol Biotechnol. 2010; 85(5):1491-1498. doi: 10.1007/s00253-009-2198-y.

11. Buttner R, Bode R, Birnbaum D. Alcoholic fermentation of starch by Arxula adeninivorans. Zbl Mikrobiol. 1992; 147(3-4):225-230. doi: 10.1016/S0232-4393(11)80333-1.

12. Kurtzman C, Fell JW. The Yeasts - A Taxonomic Study. 4th Edition. Amsterdam: Elsevier; 1055p.

13. Golovach TN, Kovalenko NK. [Microflora of silage: amylolytic lactic acid bacteria] Mikrobiol Z. 1994; 56(2):3-7. Russian.

14. Rukhlyadeva AP, Polygina GV. Metody opredeleniya aktivnosti gidroliticheskikh fermentov [Methods for determining the activity of hydrolytic enzymes]. Moscow: Pischevaya promyshlennost' [Food Industry]; 1981. 288 p. Russian.

15. Kvasnikov E, Nesterenko O. Molochnokislye bakterii i puti ikh ispol'zovaniya [Lactic acid bacteria and ways to use them]. Moscow.: Nauka; 1975. 384 p. Russian.

16. Sneath PHA, Mair NS, Sharpe ME, Holt JG, editors. Bergey's Manual of Systematic Bacteriology. 1st ed., vol. 2. Williams \& Wilkins, Baltimore; 1986.

17. Nagornaya SS, Zharova VP, Kotlyar AN. [Yeastantagonists in the normal microflora of the intestine tract in long-living people of Abkhazia]. Mikrobiol Z. 1989; 51(5):34-39. Russian.

18. Chandel AK, Chandrasekhar G, Radhika K, Ravinder R, Ravindra P. Bioconversion of pentose sugars into ethanol: A review and future directions. Biotechnol Mol Biol Rev. 2011; 6(1):008-020.

19. Darku ID, Richard TL. Biofuels: ethanol producers in eLS (Chichester, UK: John Wiley 
\& Sons, Ltd.). doi: 10.1002/9780470015902. a0020373.

20. Verma G, Nigam P, Singh D, Chaudhary K. Bioconversion of starch to ethanol in a single-step process by coculture of amylolytic yeasts and Saccharomyces cerevisiae 21. Biores Technol. 2000; 72(3):261-266. doi: 10.1016/S09608524(99)00117-0.

21. Horn CH, du Preez JC, Kilian SG. Fermentation of grain sorghum starch by co-cultivation of Schwanniomyces occidentalis and Saccharomyces cerevisiae. Bioresour Technol. 1992; 42 (1):27-31.

22. Jeon BY, Kim DH, Na BK, Ahn DH, Park DH. Production of ethanol directly from potato starch by mixed culture of Saccharomyces cerevisiae and Aspergillus niger using electrochemical bioreactor. J Microbiol Biotechnol. 2008;18 (3):545-51.

23. Rath S, Singh AK, Masih H, Kumar Y, Peter JK, Singh P, Mishra SK. Bioethanol production from waste potatoes as an environmental waste management and sustainable energy by using cocultures Aspergillus niger and Saccharomyces cerevisiae. Int J Adv Res. 2014; 2 (4):553-563.

24. Yeunyaw P.-N, Yuwa-amornpitak T. Bioconversion of cassava starch to bio-ethanol in a single step by co-cultures of Amylomyces rouxii and Saccharomyces cerevisiase. Songklanakarin J Scie Technol. 2018; 40 (4):776-783.

25. Tantipaibulvut S, Pinisakul A, Rattanachaisit P, Klatin K, Onsriprai B, Boonyaratsiri K. Ethanol production from desizing wastewater using co-culture of Bacillus subtilis and Saccharomyces cerevisiae. Energy Procedia. 2015; 79:10011007.

26. Lacerda IC, Miranda RL, Borelli BM, Nunes AC, Nardi RM, Lachance MA, Rosa CA. Lactic acid bacteria and yeasts associated with spontaneous fermentations during the production of sour cassava starch in Brazil. Int J Food Microbiol. 2005; 105(2):213-219. doi: 10.1016/j.ijfoodmicro.2005.04.010.

27. Arroyo-López FN, Bautista-Gallego J, Domínguez-Manzano J, Romero-Gil V, Rodriguez-Gómez F, García-García P, Garrido-Fernández A,
Jiménez-Díaz R. Formation of lactic acid bacteria-yeasts communities on the olive surface during Spanish-style Manzanilla fermentations. Food Microbiol. 2012, 32(2):295-301. doi: 10.1016/j.fm.2012.07.003.

28. Ponomarova O, Gabrielli N, Sévin DC, Mülleder M, Zirngibl K, Bulyha K, Andrejev S, Kafkia E, Typas A, Sauer U, Ralser M, Patil KR. Yeast creates a niche for symbiotic lactic acid bacteria through nitrogen overflow. Cell Syst. 2017; 5(4):345-357. doi: 10.1016/j. cels.2017.09.002.

29. Hirai S, Kawasumi T. Enhanced lactic acid bacteria viability with yeast coincubation under acidic conditions. Biosci Biotechnol Biochem. 2020; 84(8):1706-1713. doi: 10.1080/ 09168451.2020 .1756213$.

30. Scheirlinck T, Mahillon J, Joos H, Dhaese P, Michiels F. Integration and expression of alpha-amylase and endoglucanase genes in the Lactobacillus plantarum chromosome. Appl Environ Microbiol. 1989; 55(9):2130-2137.

31. Scheirlink T, de Meutter J, Arnaut G, Joos H, Claeyssens M, Michiels F. Cloning and expression of cellulase and xylanase genes in Lactobacillus plantarum. Appl Microbiol Biotechnol. 1990; 5(33):534-541.

32. Narvhus JA, Gadaga TH. The role of interaction between yeasts and lactic acid bacteria in African fermented milks: a review. Int J Food Microbiol. 2003; 86(1-2):51-60. doi: 10.1016/s01681605(03)00247-2.

33. Cai Y, Benno Y, Ogawa M, Ohmomo S, Kumai S, Nakase T. Influence of Lactobacillus spp. from an inoculant and of Weissella and Leuconostoc spp. from forage crops on silage fermentation. Appl Environ Microbiol. 1998; 64(8): 2982-2987. doi: 10.1128/AEM.64.8.2982-2987. 1998.

34. Syadiah EA, Haditjaroko L, Syamsu K. Bioprocess engineering of bioethanol production based on sweet sorghum bagasse by co-culture technique using Trichoderma reesei and Saccharomyces cerevisiae. IOP Conf Ser: Earth Environ Sci. 2018; 209 (1) doi:10.1088/1755$1315 / 209 / 1 / 012018$ 
35. Pidgorskyi VS, Ianieva OD, Fomina MO, Golovach TM, Ogirchuk KS. A method of starch fermentation by the co-cultivation of yeast and bacteria, Patent for utility model № 126775, Zab- olotny Institute of Microbiology and Virology of National Academy of Sciences of Ukraine, Kyiv, Ukraine, 2018.

Received 8.04.2021 